\title{
Research on Information Disclosure of Social Responsibility of Petroleum Enterprises in China-Take Petro China (Company Code: 601857) as an Example
}

\author{
Jingyuan $\mathrm{Fu}^{1}$, Zhida Guo ${ }^{2,}$, , Jingzhu Hong ${ }^{3}$ \\ ${ }^{1}$ Information Technology Studies, The University of Hong Kong, Hong Kong, China \\ ${ }^{2}$ School of Economics and Management, Dalian Jiaotong University, Dalian, China \\ ${ }^{3}$ School of Economics and Management, Shanghai Maritime University, Shanghai, China \\ Email address: \\ jingyuanfu122@163.com (Jingyuan Fu), zhidaguo@163.com (Zhida Guo) \\ ${ }^{*}$ Corresponding author
}

\section{To cite this article:}

Jingyuan Fu, Zhida Guo, Jingzhu Hong. Research on Information Disclosure of Social Responsibility of Petroleum Enterprises in China-Take Petro China (Company Code: 601857) as an Example. Automation, Control and Intelligent Systems.

Vol. 7, No. 2, 2019, pp. 54-64. doi: 10.11648/j.acis.20190702.11

Received: February 22, 2019; Accepted: April 25, 2019; Published: June 15, 2019

\begin{abstract}
With the economic globalization and the rapid development of enterprises, issues related to petroleum leakage, food safety and environmental pollution have become more and more severe, directly affecting human living environment, social harmony and the development of enterprises. At the same time, many listed companies begin to focus on releasing reports with respect to social responsibility, sustainable progress and environmental protection. Using the social responsibility report of Petro China Co. Ltd. as a case, this paper analyzes the current situation of social responsibility information disclosure of China's petroleum enterprises and existing problems in order to provide suggestions for improving the social responsibility information disclosure quality of petroleum enterprises.
\end{abstract}

Keywords: Social Responsibility Information Disclosure, Corporate Social Responsibility, Accounting Information Disclosure, Access to Information

\section{Introduction}

Since the birth of the term "social responsibility accounting" in 1968, social responsibility reporting has developed rapidly in Western countries and has been widely used in enterprises in various industries [1]. The introduction of a large number of foreign policy documents has promoted listed companies to disclose social responsibility information actively. In addition, relevant information about social responsibility in the company's annual financial statements is also disclosed. Due to the high possibility of pollution, the petroleum industry should pay more attention to shouldering social responsibility than other ordinary enterprises. Moreover, given the recent petroleum spill pollution incidents, the public start to hold more expectations for petroleum enterprises in fulfilling their social responsibilities. During this process, petroleum enterprises can protect the interest of all stakeholders. Taking China's petroleum enterprises for example, they can disclose the social responsibility information for presenting the performance of corporate social responsibility, which is beneficial for the enhancement of their international images and strengthening their competitiveness in the global market. However, the study of corporate social responsibility information disclosure in China started late. There is still a lack of a unified standard concerning the disclosure of social responsibility information. In China, most petroleum enterprises do not release corporate social responsibility report independently. To be specific, they fail to provide systematic and complete disclosures of their social responsibilities, which therefore cannot meet the information needs of stakeholders. The industry characteristics of petroleum enterprises determine their social responsibility and social impact. In recent years, many news like "Penglai 19-3 oil spill incident" has exposed the shortcomings of oil companies in disclosing social responsibility information. 
Many oil spills have made oil companies aware of their obligations to assume social responsibility and the importance of publicizing the implementation of social responsibility to stakeholders. Therefore, it is necessary to study the disclosure of social responsibility of specific enterprises such as oil enterprises. This paper takes PetroChina as an example to discuss the relevant issues of the declaration of social responsibility information of Chinese petroleum enterprises.

\subsection{The Concept of Corporate Social Responsibility}

Corporate Social Responsibility (CSR) has drawn attention from governments, businesses, academics, stakeholders and the community as a whole [2]. Corporate Social Responsibility program or commonly abbreviated as CSR program according to are actions that appear to further some social good, beyond the interest of the firm and that which is required by law [3]. CSR can be well-defined as the progressing organizational commitment to work for the betterment of the workforce of the organization to attain ethical values as well as to improve the overall performance of the organization [4]. One of the advantages of engaging in CSR is that it can improve the firm's reputation [5-7]. Enhanced stakeholder perceptions are a valuable resource that will lead to improved financial performance [8].

The concept of corporate social responsibility (CSR) originally came from overseas. Clark, J. Maurice (1916), a professor at the University of Chicago, first introduced the term "CSR" in his article, The Change Basis of Economic Responsibility [9]. However, the author did not define CSR, instead expressing his belief that "enterprises should be self-reliant, and most of the responsibilities in society come from enterprises." In 1953, Bowen (1953) expounded the concept of CSR in light of multinationals' accounting practices, stating that "Enterprises have the obligation to define policies, make decisions and take action in accordance with social objectives." Moreover, Bowen believed that voluntary CSR is a viable means of improving economic conditions and better realizing economic goals [10]. Friedman (1968) considered that, while a natural person can bear responsibility, an enterprise cannot be held responsible for its actions [11]; however, "corporate social responsibility is the economic responsibility of shareholders." Just over a decade later, Carroll (1979), a professor at the University of Georgia, pointed out that CSR exists at four distinct levels: Economical Responsibility, Legal Responsibility, Ethical responsibility, and Charitable Responsibility, all of which can then be organized into the CSR Pyramid model [12]. Besides, many scholars have complemented and perfected CSR, with the most representative point having been put forward by Koehn and Ueng (2010), who offered two hypotheses. One of which is the ethical hypothesis, which states that, because enterprises aim to become citizens in society, they fulfill social responsibility [13]. The other is the social responsibility hypothesis, which states that the purpose of social activities is to increase overall wealth. In this paper, the concept of CSR refers to enterprises creating economic benefits and assuming the responsibility of various stakeholders [14]. Here, stakeholders refer to shareholders, employees, consumers, communities and the ecological environment. CSR requires enterprises to stop thinking about profit as the sole goal and pay more attention to social harmony, ecological civilization and sustainable development.

\subsection{The Concept of Social Responsibility Information Disclosure}

In 2002, Kim et al. mentioned that high-quality social responsibility information disclosure reflects corporate ethics standards, which discourages management from concealing information and manipulating earnings. In addition to this, Gao (2014) proposed that CSR reports disclose more non-financial information, which helps to reduce insider trading and tax evasion and thereby to inhibit the selective disclosure of negative information [15]. Social Responsibility Information disclosed by listed corporations could be a meaningful way to transfer non-financial information to the stock exchange, which affects the level of stock price synchronicity. To explore whether CSR information is valuable in raising capital market pricing efficiency, Dai et al., (2018) conducted empirical research based on a sample of China Shanghai, and Shenzhen A-share listed companies in years 2010-2015 [16]. Social responsibility information disclosure relates to the long-term development of enterprises [17].

The growing international concentrate on economic and environmental sustainability has triggered a trend toward requiring companies to disclose their company social responsibility activities [18]. CSR activities encompass organizational social and environmental behavior that goes beyond the legal or regulatory requirement of the relevant market and economy. This tendency toward requiring CSR disclosure is of particular interest to regulators, investors, and stakeholders, especially in emerging economies [19-20].

The content and disclosure methods cover what and how to disclose the issue, while disclosure systems include disclosure objectives, disclosure motivation, disclosure principles, disclosure content, disclosure models and the disclosure itself [21]. These are the six distinct aspects of supervision. Similar to enterprises announcing their financials every year through annual reports, the difference between the disclosure of CSR information and the disclosure of traditional financial accounting information predominantly manifests as follows [22]. Firstly, the disclosure of content and social responsibility information is analogous to social benefits and social costs [23]; on the other hand, Financial Council accounting information disclosed as assets, liabilities and other elements. Secondly, the primary users of social responsibility information are the people of the public and stakeholders, whereas the primary users of financial accounting information are investors and creditors. Other differences pertain to the form of information disclosure, which are the social responsibility report and the financial report. Finally, the core purpose of reports and the role of social responsibility information is to analyze CSR performance and to maximize social benefits [24], despite the fact the role of financial 
accounting information disclosure is to maximize the economic benefits to enterprises. More recently, Gallego et al. (2016) proposed that the disclosure of social responsibility information refers to the use of specific methods and technologies to determine the status of CSR and its impact on business results and financial conditions [25]. Also, Alani (2015) claimed that the performance difference between CSR information disclosure and traditional accounting information disclosure is that the former goes beyond corporate economic responsibility to include CSR information [26].

The concept of social responsibility information disclosure in this paper refers to the phenomenon by which an enterprise informs on the details of its accounting and non-accounting information through annual financial reports, social responsibility reports, as well as its contribution to society and social impacts, which detailed on its official website. In the meantime, it is convenient for the government to engage in macro management [27].

\subsection{The Necessity of CSR Information Disclosure}

In the past decade, international oil companies, such as ExxonMobil and Royal Dutch Shell, have published social responsibility reports as a tool to enhance their brand value, expand their international influence and promote sustainable and long-term development. Therefore, discussing the issues related to social responsibility information disclosure in China's petroleum enterprises is of great theoretical significance and practical value. While international research began at an earlier date, the practical research is yet to be improved. Hence, there exists no unified conclusion on social responsibility information disclosure. In China, the studies on social responsibility information disclosure started relatively late. At the time of writing, disclosure information and standards are incomplete in Chinese enterprises. One such issue is the lack of third-party examinations. Consequently, the study of Chinese petroleum enterprises' social responsibility information disclosure can provide a theoretical reference for improving the social responsibility disclosure system. As far as practical value is concerned, social responsibility information disclosure by enterprises is necessary in order to protect the environment and realize sustainable societal development. As a state-owned holding enterprise, enterprises that specialize in petroleum should exemplify social responsibility by actively meeting the needs of different stakeholders, enhancing the image of enterprises and improving their international competitive power. Petroleum, as the blood of industry and a valuable strategic resource, occupies a prominent position in national economic development. Moreover, the nature of petroleum enterprises dictates that all stakeholders require the information within financial statements to be highly transparent. Such information may influence stakeholders' decisions on whether or not to purchase stocks from a particular company. As such, for the development of China's oil-based companies, improving social responsibility information disclosure is pivotal. At present, the major Chinese oil-focused corporations have been neither standardized nor systematized in their issuing of social responsibility reports. Most domestic petroleum enterprises have developed rapidly due to the excessive consumption of petroleum resources and the destruction of the natural environment. As society turns towards sustainable development, corporate values and the demands for social responsibility from social stakeholders at petroleum enterprises are gradually increasing, which will undoubtedly impact decision makers. Therefore, the social responsibility information provided by enterprises should satisfy both, internal and external requirements.

In June 2018, the 13th China International Forum on CSR held in Beijing, and the 2017 "Golden Bee CSR China List" published. In 2015, "Made in China 2025" was first proposed in the "13th Five-Year Plan", calling for the elimination of backward enterprises, the upgrading, and transformation of traditional industries and the realization of economic restructuring. In other words, "Made in China 2025" marks the beginning of a new industrial revolution. In this context, according to the fourth "Golden Bee CSR Index Report," in 2016, China's CSR practices realized significant progress, with the practice index reaching the highest level in history and CSR performance exhibiting an increasing trend towards stakeholders. The forum further discussed CSR and its implication as a tool for realizing the UN 2030 sustainable development goals. PetroChina, as a great enterprise mentioned in the "Golden Bee CSR China List," is exemplary in its fulfillment of social responsibility and disclosure of social responsibility information. Therefore, this paper selects the relevant reports of PetroChina as a case study to explore and analyze the issue of social information disclosure by petroleum-based organizations in China.

\section{The Status Quo and Problems of CSR Information Disclosure in China's Petroleum Enterprises}

In March 2005, the China National Offshore Petroleum Corporation (CNOOC) issued its first "Sustainable Development Report of CNOOC." Since then, more and more petroleum enterprises have issued social responsibility reports Social responsibility disclosure is becoming increasingly more detailed. The release of social responsibility related reports has become one of the principal means of disclosing social responsibility accounting information by China's petroleum establishments. In order to analyze the problems about the disclosure of social responsibility accounting information by listed companies in China, it is necessary to understand how Chinese petroleum businesses fulfill their social responsibility and disclose relevant information [28].

\subsection{Status Quo of Social Responsibility Information Disclosure by Chinese Petroleum Enterprises}

The listed Chinese oil companies predominantly utilize their official websites in order to disclose their annual financial reports as well as their CSR performance. Certain enterprises independently release social responsibility reports 
in order to disclose social responsibility accounting information. This paper selects 30 petroleum enterprises, listed across different years, as the research object in order to study the disclosure of social responsibility accounting information by Chinese petroleum ventures.

Table 1. Enterprises with independent CSR reports.

\begin{tabular}{llll}
\hline Stock code & Stock abbreviation & Full name of enterprise & Time to market \\
\hline $000819 . \mathrm{SZ}$ & Yueyang Xingchang & Yueyang Xingchang Petro-chemical Co., Ltd & $1997-06-25$ \\
$00883 . \mathrm{HK}$ & CNOOC & ChinaNational Offshore Oil Corporation & $2001-02-28$ \\
$600028 . \mathrm{SH}$ & Sinopec & China Petroleum and Chemical Corporation & $2001-07-16$ \\
$600583 . \mathrm{SH}$ & COOEC & Offshore Oil Engineering Co.,Ltd. & $2002-02-05$ \\
$600688 . \mathrm{SH}$ & Shanghai Petrochemical & Sinopec Shanghai Petrochemical Company Limited & $1993-11-08$ \\
$600871 . \mathrm{SH}$ & SOSC & Sinopec Oilfield Service Corporation & $1995-04-11$ \\
$601808 . \mathrm{SH}$ & COSL & China Oilfield Services Limited & $2007-09-28$ \\
$601857 . \mathrm{SH}$ & PetroChina & PetroChina Company Limited & $2007-11-05$ \\
\hline
\end{tabular}

Table 2. Enterprises without Independent CSR Reports.

\begin{tabular}{|c|c|c|c|c|c|}
\hline Stock code & Stock abbreviation & Full name of enterprise & $\begin{array}{l}\text { Time to } \\
\text { market }\end{array}$ & $\begin{array}{l}\text { Annual } \\
\text { report }\end{array}$ & $\begin{array}{l}\text { Website announces social } \\
\text { responsibility fulfillment }\end{array}$ \\
\hline 000096.SZ & Guangju Energy & Shenzhen Guangju Energy Co., Ltd. & $2007-07-24$ & $\sqrt{ }$ & $\sqrt{ }$ \\
\hline 000407.SZ & Shengli Stock & Shandong Shengli Co., Ltd. & $1996-07-03$ & $\sqrt{ }$ & $\sqrt{ }$ \\
\hline 000554.SZ & $\begin{array}{l}\text { Sinopec Shandong Taishan } \\
\text { Petroleum }\end{array}$ & Sinopec Shandong Taishan Petroleum Co., Ltd & $1993-12-15$ & $\sqrt{ }$ & $x$ \\
\hline 000617.SZ & CNPC Capital & CNPC Capital co., Ltd & 1996-10-22 & $\sqrt{ }$ & $x$ \\
\hline 000637.SZ & Mahua Shihua & Maoming Petrochemical Shihua Co., Limited & 1996-11-14 & $\sqrt{ }$ & $x$ \\
\hline 000698.SZ & SYCC & Shenyang Chemical Industry Limited company & 1997-02-20 & $\sqrt{ }$ & $x$ \\
\hline 000852.SH & SOEC & Sinopec Oilfield Equipment Corporation & $1998-11-26$ & $\sqrt{ }$ & $\times$ \\
\hline 000866.SZ & Yangzi Petrochemical & Sinopec Yangzi Petrochemical Co., Ltd. & $1998-05-12$ & $\sqrt{ }$ & $\times$ \\
\hline 000985.SZ & Daqing Hua Ke & Daqing Hua Ke Limited company & $2000-07-26$ & $\sqrt{ }$ & $\times$ \\
\hline 002207.SZ & ST Zhunyou & $\begin{array}{l}\text { Xinjiang Zhundong Petroleum Technology Co., } \\
\text { Ltd. }\end{array}$ & 2008-01-28 & $\sqrt{ }$ & $x$ \\
\hline 002221.SZ & Donghua energy & Oriental Energy Co., Ltd & 2008-03-07 & $\sqrt{ }$ & $x$ \\
\hline 002267.SZ & $\begin{array}{l}\text { Shaanxi Provincial Natural } \\
\text { Gas }\end{array}$ & Shaanxi Provincial Natural Gas co., LTD & 2008-07-31 & $\sqrt{ }$ & $\sqrt{ }$ \\
\hline 002377.SZ & $\begin{array}{l}\text { Guochuang } \\
\text { Hi-tech }\end{array}$ & $\begin{array}{l}\text { Hubei GuoChuang high tech materials Limited } \\
\text { by Share Ltd }\end{array}$ & 2010-03-23 & $\sqrt{ }$ & $\sqrt{ }$ \\
\hline 002469.SZ & SDSUNWAY & $\begin{array}{l}\text { Shandong Sunway Petrochemical Engineering } \\
\text { Co., Ltd. }\end{array}$ & 2010-09-08 & $\sqrt{ }$ & $\times$ \\
\hline 002554.SZ & HBP & China Oil HBP Group Co., Ltd & $2011-02-25$ & $\sqrt{ }$ & $\times$ \\
\hline 300157.SZ & LandOcean & LandOcean Group Limited & 2011-01-07 & $\sqrt{ }$ & $x$ \\
\hline 300164.SZ & TPI & Tong Oil Tools Co., Ltd. & 2011-01-13 & $\sqrt{ }$ & $x$ \\
\hline 300191.SZ & Sinogeo & Sino Geophysical Co., Ltd. & 2011-03-16 & $\sqrt{ }$ & $x$ \\
\hline 3983.HK & CHINA BLUECHEM & China Blue Chemical Limited company & $2006-09-29$ & $\sqrt{ }$ & $\sqrt{ }$ \\
\hline 600157.SH & Wintime Energy & Wintime Energy Co.,Ltd. & $1998-05-13$ & $\sqrt{ }$ & $\times$ \\
\hline 600339.SH & $\begin{array}{l}\text { China petroleum } \\
\text { Engineering }\end{array}$ & China Petroleum Engineering Co., Ltd. & $2000-12-25$ & $\sqrt{ }$ & $x$ \\
\hline 600387.SH & Hai Yue Energy & Hy Energy Group Co., Ltd. & $2004-02-18$ & $\sqrt{ }$ & $\times$ \\
\hline
\end{tabular}

This paper refers to the social responsibility reports, annual financial reports, and social responsibility information, which disclosed on the official websites of the 30 listed oil companies in 2018. At present, 22 of these listed on the Hong Kong Stock Exchange, Shanghai Stock Exchange or Shenzhen Stock Exchange. They have not issued independent social responsibility reports. Accordingly, the other eight firms have, and they are listed as follows: Yueyang Xingchang (000819), CNOOC (00883), Sinopec (600028), COOEC (600583), Shanghai Petrochemical (600688), SOSC (600871), COSL (601808) and PetroChina (601857). Of these, Yueyang Xingchang (000819), CNOOC (00883) and SOSC (600871) are private enterprises, while Shanghai Petrochemical
(600688), COSL (601808) and PetroChina (601857) are all state-owned enterprises (SOEs), and are engaged in the processing of crude oil and the producing of various petroleum by-products. Meanwhile, CNOOC (00883) and Sinopec (600028) are both central enterprises with very large-scale capital operations and integrated upstream and downstream petrochemical operations. These five companies, as SOEs and central enterprises in particular industries, should be industry leaders in their social responsibility fulfillment. As such, the requirements for their disclosure of social responsibility accounting information are relatively high.

Based on the contents mentioned above, as supplemented by the social responsibility and annual financial reports by 
listed Chinese oil companies and the social responsibility information disclosed on their official websites, statistical analysis was carried out. This analysis took into account the perspectives of the following stakeholders: shareholders, creditors, employees, consumers, cooperators, competitors, public interest groups and the ecological environment. The annual financial reports, social responsibility reports and the disclosure of social responsibility accounting information, about the above eight aspects of stakeholders in 2018, are shown in Table 3.

Table 3. Statistics of 30 Enterprises' Social Responsibility Information Disclosure.

\begin{tabular}{|c|c|c|c|}
\hline Stakeholder & Project & Number of enterprises & Proportion \\
\hline \multirow{3}{*}{ Shareholder } & Corporate Governance & 15 & $50.00 \%$ \\
\hline & Shareholders' Equity & 30 & $100.00 \%$ \\
\hline & Economic Benefit & 11 & $36.67 \%$ \\
\hline Creditor & Creditor's Equity & 14 & $46.67 \%$ \\
\hline \multirow{2}{*}{ Staff } & Employee Rights and Interests & 18 & $60.00 \%$ \\
\hline & Human Resources Development & 14 & $46.67 \%$ \\
\hline Consumer & Post-sales Service & 12 & $40.00 \%$ \\
\hline Collaborator & Enterprise Credit & 16 & $53.33 \%$ \\
\hline Competitor & Business Ethics & 12 & $40.00 \%$ \\
\hline \multirow{2}{*}{ Public Interest Group } & Public Welfare Establishments & 26 & $86.87 \%$ \\
\hline & Community Events & 13 & $43.33 \%$ \\
\hline \multirow{2}{*}{ Ecological Environment } & Information on the Discharge of Pollutants & 11 & $36.67 \%$ \\
\hline & Investment in Environmental Protection & 5 & $16.67 \%$ \\
\hline
\end{tabular}

According to Table 3, it demonstrates the content of social responsibility accounting information disclosure based on the statistical analysis of the social responsibility reports published on the above 30 enterprises. In general, these corporations have disclosed investor rights and interest information either in their annual financial report or their social responsibility report. Most of these enterprises have disclosed the social responsibility information concerning employee rights and interests, corporate credit, public welfare activities, as well as environmental protection policies and measures. This table indicates that most of the enterprises, by industry trends, have placed more of an emphasis on their employees as well as the reputation and branding of the enterprise.

Secondly, these 30 companies have disclosed information relating to shareholders' rights and interests, indicating that these enterprises attach great importance to protecting the interests of shareholders. During the statistical analysis, it found that eight independent CSR reporting companies have disclosed significantly more details than those that did not publish CSR reports, covering almost every indicator listed in Table 3. Secondly, concerning social responsibility report disclosure for non-accounting information, most enterprises feature written words and formal sentences on their social responsibility as opposed to disclosing data. Moreover, there exists no unified criterion for CSR accounting information disclosure in China, which complicates the comparison and analysis of CSR report across enterprises.

In the process of disclosure, enterprises often choose to disclose information that produces a positive company image, leaving out such information can often result in punishment concerning excessive pollution. A selected few, such as Guangju Energy (000096) and Shengli Stock (000407), disclose less information in their financial reports. In 2017, these firms only briefly described their social welfare activities, confirming their participation in poverty alleviation activities and their development of human resources, such as strengthening employee labor, safety, and professional skills. They did not disclose any details or provide the relevant accounting information.

Guochuang Hi-tech (002377) merely created a "social responsibility" subsection under the "corporate culture" section of their official website. In this brief section, they listed social assistance news, donations, and other public welfare activities. However, this subsection does not mention the rights and interests of other stakeholders or petroleum product quality. In contrast, CHINA BLUECHEM (3983) disclosed its social responsibility information about its corporate mission, quality control, safety, and environmental protection as well as corporate actions among others in the "Enterprise, Environment and Society" section of its website. The firm also highlighted the importance of stakeholders' rights and interests. However, in 2017, the number of companies disclosing specific types of social responsibility information were relatively few as can be inferred from Tables 3. Further to this, there is no reliable monetary basis for the content given. Hence, Chinese oil companies must pay more attention to the disclosure of social responsibility information.

It is worth mentioning that several companies have served as industry leaders, regularly issuing independent CSR reports, as well as standardizing the disclosure of their petroleum products and related customer services. A notable company is Sinopec (600028), the firm published sustainable progress reports regularly, outlining its CSR performance. The official website of Sinopec includes a "social responsibility" category and a carbon emission calculator, which concentrates on green and low-carbon development. This layout is more innovative than other enterprises, who publish their social responsibility 
reports separately. In the financial statement notes for 2017, COSL (601808) listed "payment of other cash related to business activities" as separate monetary information in order to disclose their social responsibility information on ecological environment protection. COOEC (600583) issued a report on social responsibility, including a "social responsibility" segment on its official website. The company's various public welfare activities also outlined on their website; this includes its participation in disaster relief donations at home and abroad, as well as the construction of the hope primary school.

Furthermore, the corporation released its Social Responsibility Report Monetary Information in its notice and annual report. All in all, problems persist in the disclosure of social responsibility information by listed companies in China's oil industry. Hence, further improvements required in order to perfect the current implementation.

\subsection{Problems and Causes of Social Responsibility Information Disclosure in China's Petroleum Enterprises}

In the first section, the social responsibility reports of certain petroleum enterprises that listed on the three major stock exchanges in China analyzed, while the disclosure of accounting information on petroleum enterprises' social responsibility is approximately summated. According to the disclosure of social responsibility information for petroleum enterprises in China, this section summarizes the social responsibility information concerning domestic petroleum enterprises.

\subsubsection{Disclosure Requires Comprehensiveness}

The annual report does not reflect the social responsibility assets and the following benefits associated with environmental protection. The disclosure technique that most commonly used is the publishing of a large number of written descriptions [29]. Quantitative data occasionally accompany such a technique, but rarely by financial accounting statements. Sinopec (600028) utilizes both qualitative and quantitative methods during disclosure, with a focus on qualitative disclosure and the reduction in the difficulty of report comprehension. Additionally, production safety information, such as production and maintenance of the equipment, do not reflect the Ministry of Finance's "Guidelines for the Application of Enterprise Internal Control No. 4 - Social Responsibility." The one-sidedness of information disclosure directly impacts the disclosure effectiveness of the information as well as public accuracy when evaluating CSR [30]. As stated in the reports of the 30 oil-based corporations, the annual financial reports of such companies, which do not publish social responsibility reports separately, address the economic benefits as well as the production and operation information. What's more, contemporary information disclosure methods do not directly reflect the social responsibilities that enterprises should perform, such as ecological protection, social welfare, and product information quality [31].

\subsubsection{Disclosure Comparability Requires Improvement}

Centralizing the project data disclosed in reports is somewhat tricky, as there exists no uniform standard for social responsibility reports. Moreover, there are no horizontal comparisons across different years, nor are there benchmarks for comparing different enterprises. The present situation regarding the disclosure of social responsibility information for petroleum enterprises lacks systematic norms, even in name [32], as PetroChina issued the "social responsibility report," Sinopec the "sustainable development report," and Sinopec group companies the "social responsibility report."

By comparing and analyzing the non-financial performances of the 30 listed oil companies in China in 2018, it is evident that there exists no uniform standard for the format and content of social responsibility accounting information. The evaluation index of responsibility performance is inconsistent, which complicates the statistical comparison of listed oil companies. Besides, this worsened by the weak comparability of the information. Also, most listed companies in China's oil industry disclose their social responsibility information through non-independent financial accounting reports, which is under the traditional accounting system. Only seven of the 30 listed companies disclose their social responsibility information as social responsibility reports. Hence, disclosed social responsibility information lacks systematic and complete non-financial information. CSR reports have not been widely applied. Among the eight listed oil companies that issue independent social responsibility reports, the disclosure of social responsibility information is relatively complete in the three large SOEs, namely PetroChina, Sinopec, and CNOOC. Their disclosure contents are more systematic and comprehensive when compared to other listed companies, but the formats of their reports all differ. As a consequence, the relevant government departments should establish and improve relevant regulations governing the disclosure of CSR information in China's petroleum industry, and standardize disclosure formats through unified standards, content items, and disclosure models to improve the comprehensiveness of information.

\subsubsection{Social Third-Party Examination Requires Attention}

Social responsibility information disclosure predominantly reflects the relationship between enterprises and society, especially the impact that enterprises exert on different social stakeholders. While developing their economy, businesses should simultaneously act to safeguard societal interests. However, based on the overall situation of current social and economic development, most enterprises only attach importance to economic interests, with little to no consideration of the overall social benefits. Hence, all sectors of society should be fully mobilized, a multi-level and multi-channel comprehensive supervision system should be established, and enterprises should be encouraged so that they actively and consciously fulfill their responsibilities. Different levels of social supervision can rapidly transmit varied information to the public and widen their influence.

Moreover, they can delegate tasks to their supervisory role 
in order to fulfill CSR. These propaganda organizations are capable not only to publicize enterprises that actively fulfill their social responsibilities, thereby enhancing their image and delivering significant economic and social benefits but also to urge enterprises that neglect their social responsibility to change their ways. The oil spills in the Gulf of Mexico and the tidal bay in 2010 and 2011, respectively, were reported across the media. This is so that the public can remain abreast of developments and aware of the facts. At the same time, the involved oil companies became the focus of public opinions in society, thus prompting them to take active remedial measures and assumption of social responsibility. Furthermore, their traditional financial accounting reports were examined, supervised and checked by particular auditing institutions before being issued, whereas the social responsibility reports of most petroleum companies in China are disclosed voluntarily without audit, which may limit their factual basis. The reliability of the information cannot be verified, and the public cannot censor it, which risks damaging the interests of those who use CSR information.

\section{Case Analysis of CSR Information Disclosure}

This paper selects China Petroleum Corporation Limited, a representative listed oil company in China, as the research object. On this basis, the company's social responsibility information from 2012 to 2017 is analyzed horizontally in order to determine whether the content is worthy of reference, whether it merits improvement and the reasons behind any shortcomings [28].

\subsection{Introduction to PetroChina}

China Petroleum and Natural Gas Corporation (hereinafter referred to as "PetroChina") is a public limited company with shares established on November 5, 1999, in accordance with the Company Law and the State Council's Special Regulations on Offshore Stock Raising and Listing of Joint Stock Limited Companies following the reorganization of the PetroChina Group Corporation. PetroChina, a state holding company, has always been a core enterprise among China's SOEs. PetroChina is an important SOE which was authorized by the state as an investment institution and a state holding company. PetroChina ranked thirty-third in the world's top 500 list of brands released by Brand Finance in 2017. Through its development, PetroChina has remained committed to becoming an international energy enterprise, continually improving its competitiveness and building an international brand. PetroChina is predominantly engaged in upstream and downstream industries in the oil and natural gas sector, working in oil extraction, production, and marketing, crude oil processing, crude oil refining, and transportation. Moreover, PetroChina has made outstanding contributions to China's industrialization.

\subsection{Analysis of CNPC's Report on CSR}

Since 2006, PetroChina has issued its Social Responsibility Report for two consecutive years. On February 28, 2007, PetroChina issued its 2006 CSR Report in Beijing, which was the first social responsibility report released to the public as well as the first non-financial annual report issued independently by PetroChina. This social responsibility report is constructed based on relevant information in the original annual financial report. Moreover, it marked the first time that the company systematically explained its responsibilities and related actions, thereby concretely embodying its CSR activities. From 2012 to 2017, the contents of its social responsibility report remained the same, covering business performance guidelines and objectives, environmental performance and social environmental management among other topics.

Table 4. CSR information disclosure in PetroChina during 2012-2017.

\begin{tabular}{|c|c|}
\hline Years in particular & Items \\
\hline 2012 & The report added "Integrity and Standard Corporate Control" and "Answering investor questions." \\
\hline 2013 & $\begin{array}{l}\text { Issued "Special Report on Corporate Social Responsibility of the West-East Gas Pipeline (2002-2013) and "Guidelines for the } \\
\text { Implementation of Social Responsibility" etc. }\end{array}$ \\
\hline 2014 & $\begin{array}{l}\text { To carry out relevant research on social public welfare management, CNPC published the guidelines to perform social responsibility, } \\
\text { and issue the special report on the corporate social responsibility of the West-East Gas Pipeline (2002-2013). }\end{array}$ \\
\hline 2015 & $\begin{array}{l}\text { Issued "Excellent Social Responsibility Practice Case Set of PetroChina 2014," "PetroChina Quality Upgrading Report," } \\
\text { "PetroChina } 2014 \text { Environmental Protection Report," "PetroChina Green Development Report" and so on. }\end{array}$ \\
\hline 2016 & $\begin{array}{l}\text { Issued interpretation of the six action plans for Green Development compiled by the China Petroleum and Chemical Industry } \\
\text { Federation. }\end{array}$ \\
\hline 2017 & $\begin{array}{l}\text { Issued the "special report on the corporate social responsibility of China-Myanmar oil and gas pipeline (Myanmar)," and compiled } \\
\text { the "CNPC } 2016 \text { outstanding social responsibility practice case set." }\end{array}$ \\
\hline
\end{tabular}

PetroChina disclosed CSR reports for six consecutive years from 2012 to 2017. These CSR reports generally followed the same direction, although individual differences exist between them regarding sustainable energy supplies, safe and responsible production and operation, people-oriented staff development and social contributions to promote quality of life. 
Table 5. CSR Report Form of PetroChina in 2012-2017.

\begin{tabular}{|c|c|c|c|c|c|c|}
\hline Project $\quad$ Year & 2012 & 2013 & 2014 & 2015 & 2016 & 2017 \\
\hline Name of the Report & $\begin{array}{l}\text { Enterprise } \\
\text { Society } \\
\text { Responsibility } \\
\text { Report }\end{array}$ & $\begin{array}{l}\text { Enterprise Society } \\
\text { Responsibility } \\
\text { Report }\end{array}$ & $\begin{array}{l}\text { Enterprise Society } \\
\text { Responsibility } \\
\text { Report }\end{array}$ & $\begin{array}{l}\text { Enterprise Society } \\
\text { Responsibility } \\
\text { Report }\end{array}$ & $\begin{array}{l}\text { Enterprise Society } \\
\text { Responsibility } \\
\text { Report }\end{array}$ & $\begin{array}{l}\text { Enterprise Society } \\
\text { Responsibility } \\
\text { Report }\end{array}$ \\
\hline Report Theme & $\begin{array}{l}\text { Dedicating } \\
\text { Energy, } \\
\text { Create Harmony }\end{array}$ & $\begin{array}{l}\text { Dedicating Energy, } \\
\text { Create Harmony }\end{array}$ & $\begin{array}{l}\text { Dedicating Energy, } \\
\text { Create Harmony }\end{array}$ & $\begin{array}{l}\text { Dedicating Energy, } \\
\text { Create Harmony }\end{array}$ & $\begin{array}{l}\text { Dedicating Energy, } \\
\text { Create Harmony }\end{array}$ & $\begin{array}{l}\text { Dedicating Energy, } \\
\text { Create Harmony }\end{array}$ \\
\hline $\begin{array}{l}\text { Length of Report } \\
\text { (page) }\end{array}$ & 56 & 64 & 56 & 64 & 76 & 84 \\
\hline Means of Disclosure & $\begin{array}{l}\text { Quantitative and } \\
\text { qualitative } \\
\text { analysis }\end{array}$ & $\begin{array}{l}\text { Quantitative and } \\
\text { qualitative analysis }\end{array}$ & $\begin{array}{l}\text { Quantitative and } \\
\text { qualitative analysis }\end{array}$ & $\begin{array}{l}\text { Quantitative and } \\
\text { qualitative analysis }\end{array}$ & $\begin{array}{l}\text { Quantitative and } \\
\text { qualitative analysis }\end{array}$ & $\begin{array}{l}\text { Quantitative and } \\
\text { qualitative analysis }\end{array}$ \\
\hline Report Cases (part) & 19 & 17 & 18 & 5 & 13 & 25 \\
\hline $\begin{array}{l}\text { Use form (part) } \\
\text { Number of }\end{array}$ & 7 & 10 & 9 & 13 & 19 & 22 \\
\hline $\begin{array}{l}\text { Ecological } \\
\text { Environmental } \\
\text { Indicators }\end{array}$ & 6 & 6 & 6 & 7 & 7 & 7 \\
\hline Reference Standard & $\begin{array}{l}\text { Guidelines for } \\
\text { Sustainable } \\
\text { Development } \\
\text { Report } \\
\text { (G3.0 version) }\end{array}$ & $\begin{array}{l}\text { Guidelines for } \\
\text { Sustainable } \\
\text { Development Report } \\
\text { (G4.0 version) }\end{array}$ & $\begin{array}{l}\text { Guidelines for } \\
\text { Sustainable } \\
\text { Development Report } \\
\text { (G4.0 version) }\end{array}$ & $\begin{array}{l}\text { Guidelines for } \\
\text { Sustainable } \\
\text { Development Report } \\
\text { (G4.0 version) }\end{array}$ & $\begin{array}{l}\text { Guidelines for } \\
\text { Sustainable } \\
\text { Development Report } \\
\text { (G4.0 version) }\end{array}$ & $\begin{array}{l}\text { Guidelines for } \\
\text { Sustainable } \\
\text { Development Report } \\
\text { (G4.0 version) }\end{array}$ \\
\hline $\begin{array}{l}\text { Language Version } \\
\text { Release Time }\end{array}$ & $\begin{array}{l}\text { Chinese and } \\
\text { English version } \\
\text { 2013-05-07 }\end{array}$ & $\begin{array}{l}\text { Chinese and English } \\
\text { version } \\
\text { 2014-04-23 }\end{array}$ & $\begin{array}{l}\text { Chinese and English } \\
\text { version } \\
\text { 2015-04-29 }\end{array}$ & $\begin{array}{l}\text { Chinese and English } \\
\text { version } \\
\text { 2016-04-28 }\end{array}$ & $\begin{array}{l}\text { Chinese and English } \\
\text { version } \\
\text { 2017-05-25 }\end{array}$ & $\begin{array}{l}\text { Chinese and English } \\
\text { version } \\
\text { 2018-05-17 }\end{array}$ \\
\hline
\end{tabular}

According to Table 5 and the previous analysis concerning the social responsibility information disclosure of the 30 listed oil companies in China, the following conclusions can be drawn.

In terms of information comprehensiveness. The theme of social responsibility reports is the embodiment of social responsibility, which reflects the orientation of the enterprise's social responsibility. The theme of the five-year report is "dedicating energy to create harmony." By this, PetroChina can adjust the words in future reports to intuitively express its different reporting priorities every year. In the context of space, proper assurance is necessary. If a simple report cannot meet the actual needs and requirements of stakeholders, its original purpose is not achieved finally. On the surface, a detailed report can meet the actual interests of the parties as fully as possible, but with significant shortcomings, such as excessively long reports, which would hinder readability. Pleon, a German consultancy, concluded that most people prefer a report of fewer than 50 pages, while a mere third prefer reports more than this. Hence, a suitable report should be limited to about 50 pages. PetroChina wrote and published a 56-page report in 2012 and 2014, which is reasonable, but their 80-page report in 2017 was unbearably long. PetroChina benefited from a combination of qualitative and quantitative methods. In its qualitative disclosure, PetroChina used several practical cases to explain its social responsibility regarding economic, cultural and environmental aspects. To explain this, in its 2017 report, PetroChina provides twenty-five distinct cases, four of which are economic, six of which are environmental, six of which apply to staff welfare and nine of which concern community and public welfare. This approach ensures their sustainable development reports are more intuitive and easier to understand. The cases can rectify the limitations of using simple text, which enhance strong ability. In this way, users can read reports more easily and conveniently. Regarding quantitative disclosure, PetroChina has 19 tables in its reports. Concerning the social responsibility report in 2014 , the number of tables is more than double that of the original. This disclosure method ensures information integrity, indicating that PetroChina has improved its information disclosure. Overall, in the past five years, the frequency of qualitative disclosure has remained relatively stable, but its content has been enriched and the frequency of quantitative disclosure gradually increased [32].

Concerning information comparability. For reference, the new version of the G4.0 requirement was employed from the 2012 Guidelines for Sustainable Development Reporting (G3.0) to 2013-2017. In the meantime, both the English and Chinese versions of the reports have been published, reflecting the fact that PetroChina keeps pace with the times and follows international standards. This means the social responsibility reports of PetroChina and other international oil companies are comparable. PetroChina complies with international standards in declaring that any paper used must be green and recyclable. The report ends with a note specifying the use of environmentally friendly paper. Hence, PetroChina, as an internationally renowned enterprise, has made significant progress in promoting sustainable development and environmental protection. However, the Guidelines for the Sustainable Development Report (G4.0) also stipulate that the reports should disclose not only positive information but also negative aspects, highlighting areas for 
improvement. PetroChina discloses mostly positive information in its reports, lacking the necessary negative information, which merits further improvement. Also, the social responsibility reports for PetroChina 2012-2017 also lack independent third-party examination, meaning their reliability cannot be verified and confirmed.

Concerning social third-party examination. Regarding the feedback mechanism for social responsibility management, the 2012-2017 reports contain feedback forms, reflecting PetroChina's efforts to be on top of the times. PetroChina also provides reference values in its feedback mechanism. To illustrate this, the questionnaire integrates opinions into each report, which serves as a means for stakeholders to evaluate report contents and feedback suggestions, while simultaneously guiding the timely adjustment of report direction.

In summary, the advantages of PetroChina's social responsibility report lie in its clear structure and multi-stakeholder perspective. Nonetheless, specific problems persist which merit attention. The inadequacies are listed as follows: the limited disclosure of negative information, the lack of independent third-party examination and limited reliability. Thus, excellent CSR reports are those who do not avoid but list relevant deficiencies or errors, thereby revealing setbacks encountered during enterprise development and growth. Hence, creditability can be improved.

Additionally, PetroChina's report is excessively long, which can reduce readability and the ability of readers to evaluate the company's social responsibility performance correctly. Overall, PetroChina's social responsibility report is picturesque and intuitive, with impressive typesetting and pictures, which successfully convey the concept of CSR. However, there is, some aspects need to be improved.

\section{Conclusion}

By investigating the social responsibility information disclosure for the 30 listed oil companies in China and their social responsibility reports, this paper summarizes the existing problems facing social responsibility information disclosure for petroleum enterprises in China, analyzing the relevant reasons. This section concludes those as mentioned above based on policy, the criteria system and supervision system, suggesting areas for improvement in Chinese petroleum enterprises' disclosure of social responsibility information.

\subsection{Strengthening Government Guidance and Support for the Disclosure of Social Responsibility Information for Listed Companies in the Petroleum Industry}

In China's current market economy, the government should apply full macro-control, protecting the development of oil enterprises while restraining them by the law. The state and government should fully assume their essential role in strategic regulation, guiding oil enterprises on the disclosure of social responsibility. It is necessary to establish a set of systematic social responsibility regulations to restrict daily operations and management behavior at petroleum corporations [28].

Similar to financial accounting, it is essential for complete and unified accounting standards to be established regarding CSR by using relevant laws as a means of guiding enterprises in fulfilling their social responsibilities and following the standards for the disclosure of social responsibility information. When enterprises undertake and fulfill their social responsibility, they should provide practical guidance and formulate clear behavior norms for the disclosure of relevant accounting information. At present, regarding social responsibility information disclosure, the relevant evaluation criteria are not unified, while the relevant content, implementation methods, and focus, all of which differ significantly [33]. This means the information remains incomparable and ineffective. In this regard, based on China's national conditions, lessons should be learned from the experience and advantages of Western countries so that social responsibility accounting standards, which are suitable for China, can be implemented. Relevant government departments should set up particular organizations to provide the necessary help and support to enterprises, offering individual guidance and evaluations that are in line with the specific characteristics of oil enterprises [15]. At the same time, while strengthening legislation, the government should also clarify and highlight the rewards and penalties, establishing a corresponding practical mechanism of rewards and punishments, while strengthening law enforcement.

\subsection{China's Perfect System of Standards Governing the Disclosure of Social Responsibility Information for Petroleum Enterprises}

In order to devise the social responsibility criteria and system for Chinese petroleum enterprises, it is crucial that political, financial and business circles are involved. First, those from a diverse range of background should analyze and subsequently put forward specific outlines. Then, the relevant departments should collate the normative laws and policies, which would then be promulgated and implemented by the Ministry of Finance. Further to this, the social benefits and costs, associated with specific content, should be explained comprehensively, and the calculation methods should be studied in the form of policy requirements for enterprises [34]. An active system requires enterprises to provide specific social responsibility information. The Social Responsibility Criteria will stipulate the basic contents, measurement methods, and external reporting principles, which petroleum enterprises must follow when reporting on their social responsibility. Gradually, enterprises will consciously disclose relevant social responsibility information to society [1].

As for form, the disclosure of off-balance-sheet annotations should be increased. Then, following a period of implementing the monetary format of reports, a valid social responsibility income statement and balance sheet will be formed, thereby disclosing CSR-related information. Meanwhile, petroleum enterprises should reform and innovate their primary mechanisms for social responsibility, making 
full use of them in order to fully demonstrate these enterprises' critical role in national economic development. With their social responsibility as an example, the sense and assumption of all enterprises' social responsibility can be improved. Relevant reports will be issued in order to achieve the sustainable development of oil enterprises.

\subsection{Perfecting the Supervisory System for Social Responsibility Information Disclosure by Petroleum Enterprises in China}

Guided by the relevant regulatory units, regulatory authorities should establish a professional third-party examination system, which can effectively evaluate the relevant information concerning the social responsibility of domestic petroleum enterprises [17]. The concerned and competent departments can specify relevant procedures, standards, and supervision to ensure that supervisory work is scientific and standardized. Meanwhile, regulatory agencies should exercise their full ability to effectively evaluate and disclose the social responsibility of domestic oil enterprises, thereby guaranteeing that the information they supply is both authentic and compelling.

Taking the supervision department as the main body, an index evaluation system should be established. Specific workflow can draw lessons from the financial information disclosure mechanism, clarifying working standards for social responsibility information disclosure. In order to strengthen the international exchange and integration of related work, the established evaluation system should follow the trend of internationalization to some extent. For listed oil companies, it is necessary to establish a suitable auxiliary evaluation system to guarantee that the information disclosed in social responsibility reports can be objectively compared [32].

\section{Conflicts of Interest}

The authors declare no conflict of interest.

\section{Acknowledgements}

This research is supported by the National Natural Science Foundation of China (No. 71771066), the Natural Science Foundation of Liaoning Province of China (No. 20170540124), and the Educational Commission of Liaoning Province of China (No. JDL2016032), the Social Science Planning Fund of Liaoning Province of China (No. L14AGL005). We would like to thank the reviewers for their valuable comments and suggestions.

\section{References}

[1] Christie, N., Dyck, B., Morrill, J., \& Stewart, R., "CSR and Accounting: Drawing on eber and Aristotle to Rethink Generally Accepted Accounting Principles", Business and Society Review, vol. 118, no. 3, pp. 383-411, 2013.

[2] Asmeri, R., Alvionita, T., \& Gunardi, A., "CSR Disclosures in the Mining Industry: Empirical Evidence from Listed Mining Firms in Indonesia", Indonesian Journal of Sustainability Accounting and Management, vol. 1, no. 1, pp. 16-22, 2017.

[3] Palmer, H. J., "Corporate social responsibility and financial performance: Does it pay to be good?", CMC Senior Theses, pp. 529-589, 2012.

[4] Mujahid, M., Abdullah, A., "Impact of corporate social responsibility on firms financial performance and shareholders wealth", European Journal of Business and Management, vol. 6 , no. 31 , pp. 181-187, 2014 .

[5] Gardberg, N. A., \& Fombrun, C. J., "Corporate citizenship: Creating intangible assets across institutional environments", Academy of Management Review, vol. 31, no. 2, pp. 329-346, 2006.

[6] Graafland, J., "Does Corporate Social Responsibility Put Reputation at Risk by Inviting Activist Targeting? An Empirical Test among European SMEs", Corporate Social Responsibility and Environmental Management, vol. 25, no. 1, pp. 1-13, 2018.

[7] Handayani, I., Sulistiyono, A., Leonard, T., Gunardi, A., \& Najicha, F. "Environmental Management Strategy in Mining Activities in Forest Area accordance with the Based Justice in Indonesia", Journal of Legal, Ethical and Regulatory Issues, vol. 21, no. 2, pp. 1-8, 2018.

[8] Walker, M., \& Mercado, H., "The Resource-worthiness of environmental responsibility: A resource-based perspective", Corporate social responsibility and environmental management, vol. 22, no. 4, pp. 208-221, 2015.

[9] Clark, J. M., "The Changing Basis of Economic Responsibility", Journal of Political Economy, vol. 24, no. 3, pp. 209-229, 1916.

[10] Bowen, H. R., Social responsibilities of the businessman, NY: Harper \& Row, USA, 1953.

[11] Friedman, M. (1962). Capitalism and freedom. Chicago, IL: University of Chicago Press.

[12] Carroll, A. B., "A three-dimensional conceptual model of corporate performance", Academy of Management Review, vol. 4, no. 4, pp. 497-505, 1979.

[13] Koehn, D., \& Ueng, J., "Is philanthropy being used by corporate wrongdoers to buy good will?", Journal of Management and Governance, vol. 14, no. 1, pp. 1-16, 2010.

[14] Zeghal, D., \& Ahmed, S. A., "Comparison of social responsibility information disclosure media used by Canadian firms", Accounting Auditing \& Accountability Journal, vol. 3, no. 1 , pp. $38-53,1990$.

[15] Gao, X. "From societization of workers' rights defending to the construction of corporate social responsibility: The experience of Yiwu City's general trade union", Social Issues in China: Gender, Ethnicity, Labor, and the Environment, vol. 1, no. 1, pp. 227-237, 2014.

[16] Dai, J., Lu, C., Yang, Y., \& Zheng, Y., "Is the Social Responsibility Information Disclosed by the Companies really Valuable?-Evidence from Chinese Stock Price Synchronicity", Sustainability, vol. 10, no. 10, pp. 1-22, 2018. 
[17] Liu, X., \& Zhang, C. J., "Corporate governance, social responsibility information disclosure, and enterprise value in China", Journal of Cleaner Production, vol. 118, no. 3, pp. 1075-1084, 2017.

[18] Chen, Y. C., Hung, M., \& Wang, Y., "The effect of mandatory CSR disclosure on firm profitability and social externalities: Evidence from China", Journal of Accounting \& Economics, vol. 65 , no. 1, pp. 169-190, 2018.

[19] Heikkurinen, P. J., "Image differentiation with corporate environmental responsibility", Corporate Social Responsibility and Environmental Management, vol. 17, no. 3, pp. 142-152, 2010 .

[20] Kitzmueller, M., \& Shimshack, J. J., "Economic perspectives on corporate social responsibility", Journal of economic literature, vol. 50, no. 1, pp. 51-84, 2012.

[21] Cormier, D., \& Magnan, M., "The impact of social responsibility disclosure and governance on financial analysts' information environment", Corporate Governance, vol. 14, no. 4, pp. 467-484, 2014.

[22] Collins C. N. "Rethinking the accounting stance on sustainable development", Sustainable Development, vol. 20, no. 1, pp. 28-41, 2012.

[23] Kim, Y. S., \& Choi, Y., “College Students' Perception of Philip Morris's Tobacco-Related Smoking Prevention and Tobacco-Unrelated Social Responsibility”, Journal of Public Relations Research, vol. 24, no. 2, pp. 184-199, 2012.

[24] Farooq A. A., \& Firdouse R. K., "Framework Development of the Social Responsibility Accounting towards Economic Units' Evaluation", International Journal of Economics and Finance, vol. 7, no. 2, pp. 253-260, 2015.

[25] Gallego-Álvarez, I., \& Quina-Custodio, I. A., "Disclosure of corporate social responsibility information and explanatory factors", Online Information Review, vol. 40, no. 2, pp. 218-238, 2016.
[26] Alani, F., "Framework development of the social responsibility accounting towards economic units' evaluation", International journal of economics and finance, vol. 7, no. 2, pp. 253-260, 2015.

[27] Loh, C. M., Deegan, C., \& Inglis, R., "The changing trends of corporate social and environmental disclosure within the Australian gambling industry", Accounting \& Finance, vol. 55, no. 3, pp. 783-823, 2015.

[28] Annual social responsibility statement of China petrochemical corporation. China Petrochemical Corporation Network. http://www.sinopecgroup.com/group/, 2018-06-24.

[29] Melo, T., Garrido-Morgado, A., "Corporate reputation: A combination of social responsibility and industry", Corporate Social Responsibility and Environmental Management, vol. 19, no. 1, pp. 11-31, 2012.

[30] Lin, H., Zeng, S., Wang, L., Zou, H., Ma, "How does environmental irresponsibility impair corporate reputation? A multi-method investigation", Corporate Social Responsibility and Environmental Management, vol. 23, no. 6, pp. 413-423, 2016.

[31] Babiak, K., \& Trendafilova, S., "CSR and environmental responsibility: motives and pressures to adopt green management practices", Corporate social responsibility and environmental management, vol. 18, no. 1, pp. 11-24, 2011.

[32] Annual social responsibility statement of CNPC. CNPC Network. Vol. 1(1) http://www.cnpc.com.cn/cnpc/index.shtml, 2018-08-25.

[33] Roberts, R. W. (1992). "Determinants of corporate social responsibility disclosure: An application of stakeholder theory", Accounting, Organizations and Society, vol. 17, no. 6, pp. 595-612.

[34] Ngwakwe, C. C., "Rethinking the accounting stance on sustainable development", Sustainable Development, vol. 20, no. 1, pp. 28-41, 2012. 